\title{
“Gerçeğin” Peşinde: Dil, Kültür, Medya ve İnsan Üzerinden Gerçekliğin Sosyal İnşasına Dair Eleştirel Bir Değerlendirme
}

\author{
Going After the "Truth": A Critical Reflection on The Construction of Reality over Language, \\ Culture, Media and Human.
}

Ayşe Simin Kara, Doç. Dr., İstanbul Ticaret Üniversitesi İletişim Fakültesi, E-posta: aserdemir@ticaret.edu.tr

https://doi.org/10.47998/ikad.864087

\author{
Anahtar Kelimeler: \\ Gerçek Ötesi, \\ Retorik, \\ Göstergebilim, \\ Sözbilim, \\ Gerçekliğin Sosyal \\ İnşası.
}

Öz

İnsan, en önemli bilişsel süreçlerden biri olan dil yetisi kazanımını elde ettiğinden bu yana geçmişten günümüze hikâye anlatıcıllğında değişmeyen unsurlar olduğunu görüyoruz. Değişmeyen unsurlara baktığımızda iyi bir hikâyenin kişisel ve duygusal bağ kurduğunu, dinleyiciyi alıp götürdüğünü ve herşeyden önemlisi harekete geçirdiğini söyleyebiliriz. Değişen tek şeyin ise hikâye anlatımının araçları olduğunu söylemek mümkün. Hikâye anlatıcılığı bir anlatı yöntemi olarak iletişimin her türünde karşımıza çıkmakta, iletişim uzmanları tarafından etkin iletişim adına bir strateji olarak konumlandırılmaktadır. Her türlü içeriğin üretildiği ve yeniden üretildiği dolayımlı bir medya ortamında yaşıyoruz. Teknolojik gelişmeler sayesinde hikâye anlatıcıların ikna gücü öyle kuvvetlenmiştir ki şekillendirilen dünyamızın aslında "gerçek" olmadığını unutuyoruz. Bu çalışmanın amacı, "gerçek" kavramına eleştirel bir bakış açısı sunmaktır. Bu bakış açısı, hipergerçekliği (gerçek ötesi), medyanın toplumun kimlik ve gerçeklik anlayışı üzerindeki etkisini vurgulayarak gerçeğin inşasını eleştirel, stratejik ve sözbilimsel olarak inceleyen post-modern perspektiften sunacaktır. Ayrıca, gazeteciliğin geleceği olarak ifade edilen mekânsal gazetecilik örneği üzerinden hakikatın inşasını konu alıp yeni teknolojilerin hiper ortam üzerinden nasıl "gerçeği” inşaa ettiklerini eleștirel bir dille yansitacaktır.

\section{Keywords:}

Hyperreality,

Rhetoric,

Semiotics,

Semantics,

Social Construction of Reality.

\section{Abstract}

Since humans mastered the aptitude to communicate by way of storytelling, one can notice that some aspects remained unchanging over the course of time. When one considers these aspects, it can be suggested that a good story has not lost its ability to establish a personal and emotional connection with the audience, move the audience, and above all engage the audience to act and behave in a certain way. Over the time, the only thing that has changed seems to be the means of storytelling. Storytelling, as a narrative method, appears in all types of communicative input and is positioned as a strategy for effective communication by communication professionals. We live in a heavily mediated environment whereby all kinds of content are produced and reproduced. Paved by technological developments, the persuasive power of storytellers have become so strong that we forget that our world is not actually "real". The aim of this study is to present a critical perspective to the concept of "reality". This perspective will present hyperreality (post-real) from a post-modern perspective that examines the construction of reality critically, strategically and rhetorically, placing a special emphasis on the influence of media in shaping society's understanding of identity and reality. In addition, this paper will query the construction of truth through the example of spatial journalism and critically reflect how new technologies construct the "truth" through the long hived hyper media. 


\section{“İnsanoğlunun iletişim sağladı̆̆ı medyanın doğası, toplumları her zaman, iletişimin içeriğinden daha çok şekillendirmiştir”.}

— MARSHALL MCLUHAN (1964:1)

\section{Giriş}

İnsanoğlu, varlığını sürdürebilmek ve dünyayı anlayabilmek için iletişim kurmak zorundadır. Bu zorunluluğu yerine getirebilmek için anlama ve anlatma ihtiyacına gerek duyar. Hikâye anlatımı evrenseldir ve insanlık kadar eskidir. Her kültürde ve her çağda karşımıza çıkan hikâye anlatımı, bilgilendirme, bilgiyi yayma, eğlendirme, kültürel gelenek ve değerleri aktarma işlevinin yanında nasıl düşündüğümüzün, hissettiğimizin, hatırladığımızın, hayal ettiğimizin, ilişkilendirdiğimizin ve değişim yarattığımızın önemli bir parçası olmuştur. Hikâye anlatıcılığı bir anlatım biçimi olarak mağara resimleri gibi görsel anlatılarla serüvenine başlamış ve insanoğlu dil yetisini kazandıktan sonra hikâyelerin ağızdan ağıza bir nesilden diğerine aktarıldığı sözlü gelenekler halini almıştır. Zamansızlığıyla dikkat çeken hikâye anlatıcılığında yüzyıllar boyu değişmeyen unsurlar olduğunu görmek mümkündür. Değişmeyen unsurlara baktığımızda iyi bir hikâyenin kişisel ve duygusal bağ kurduğunu, dinleyiciyi alıp götürdüğünü ve herşeyden önemlisi harekete geçirdiğini söyleyebiliriz. Teknoloji geliştikçe değişen tek şeyin ise hikâye anlatımının araçları olduğunu söylemek mümkün. İnsan, dil yetisi kazanımından önce binlerce yıl boyunca sözsüz iletişime güvendi ancak ilkel çağlardan itibaren varlığını sürdüren iletişim matbaa, kamera, internet ve sosyal medya platformlarının öncülügüüü yaptığı gelişen teknolojilerle birlikte sözsüz iletişimle başladığı serüvenini günümüzde 3D modelleme ve yapay zeka teknolojilerinin birlikte kullanılmasıyla insanların iletişim kurma ve anlatıya ulaşma şeklini tamamen değiştiriyor.

Çift yönlü iletişim, günümüzün hızla değişen sosyo-ekonomik yapısında oldukça önemlidir. Çeşitli iletişim mesajlarıyla aktarılan içeriklerin sayısı ve sıklığı arttıkça insanların dikkat aralığ 1 da bir o kadar hızlı bir şekilde daralmaya başlamıştır (theguardian, 2019). İçerik tüketimi konusunda hassaslaşan kitleler, maruz kaldıkları görsel ve işitsel kirlilik karşısında daha seçici davranmakta ve çeşitli filtreler aracılığıyla gözleri, kulakları ve beyni tırmalayan iletileri azaltmanın peşine düşmektedir. Bu yüzden de daha cazip, sürükleyici ve katılıma teşvik edici bir konuşma tarzına gerek duyulmaktadır. Teknolojideki gelişmeler sayesinde gönderici ile alıcı arasındaki mesafe gittikçe azalmakta, iletişimde kapsayıcılık ve ilişki kurma ihtiyacı gittikçe artmaktadır. İletişim; sadece bir göndericinin, bir alıcının ve bir iletinin olduğu basit bir model ile tanımlanamaz. Bu sistem; göndericinin ve alıcının duygularını, hislerini ve iletiyi nasıl yorumladıklarını ve iletiye göre nasıl hareket ettiklerini de kapsar. Bu oldukça öznel yorumlama ve eyleme kanaat getirme sanatının doğası gereği, hikâye anlatımı herhangi bir başka iletişim şeklinden çok daha üstündür. Hikâye anlatımı, hikayelerin ve anlatıların kullanıldığ 1 bir iletişim sanatı olarak tanımlanabilir. Dünya üzerindeki tüm kültürlerde var olmuş olan ve günümüzde çeşitli kitle iletişim araçları vasıtasıyla kitlelere seslenen hikâye anlatıcıları kuşaktan kuşağa aktarılan, kıtaları aşan ve toplumu değiştiren anlatımlarla yaşadığımız dünyayı şekillendirmiştir. Teknolojik gelişmeler sayesinde hikâye anlatıcıların ikna gücü öyle kuvvetlenmiştir ki şekillendirilen dünyamızın aslında gerçek olmadığını unuturuz. 
Gördüklerimizin büyük oranda medya tarafindan şekillendirildiği ve filtreden geçtiği teknolojik açıdan zengin bir toplumda yaşıyoruz (Özgen, 2019, s. 3385). Doğru, özgün ya da gerçek olarak bildiklerimiz algımıza şırıngalanan, gerçeğinden arındırılıp içi boşaltılmış, bir amaç doğrultusunda medyasallaştırılmış, piyasada takas değeri olan yapay bir üründen ibaret. Gerçeğin yerini alan bu insan yapımı temsillerin ya da "şey"lerin gerçeği ilişkilendirmemizdeki etkisi ise çok büyük (Adorno, \& Horkheimer, 1997, s.28). Gerçek olarak bildiğimiz, gerçeğin bir yansıması ya da bir temsili değil, dolayımlama üzerinden gerçeğin yeniden yaratılmasıyla yeni bir kültürü doğuran medya kültüründe, medya kamusal alanı dönüştürmüş ve arkasında yeni bir görsel miras ve bilinç imparatorluğu bırakmıştır (MacDonald, 2006, s. 508). Tarihsel bağlamda, medya, kurumsal hakimiyet, tüketimcilik, teknoloji ve popüler kültür gibi hegemonik boyutta çok kuvvetli küresel piyasa güçlerinin bir olup büyük anlatıyı aktardığ 1 bir alan olmuştur (Lyotard, \& Brügger, 2001). Lyotard, büyük anlatıyı bilim ve devleti meşrulaştırmak amacıyla kullanılan üst anlatıların oynadığı rol olarak ifade etmiştir (Browning, 2000). Medyatik anlatının gerçek olayların bir temsili olduğunu düşünürsek, temsillerden oluşan ve temsillerin ise işaretlerden (göstergelerden) oluştuğu bir dünyada yaşadığımızı söyleyebiliriz (Baudrillard, 1988). Bu oluşumda medya sembolik olanı işaretler aracılığıyla kendi ideolojik amacı doğrultusunda yeniden üreterek işaretlerin yorumlanmasında, üretilmesinde veya işaretleri yorumlama süreçlerinde anlam bütünleri kurmada ve bunları dünya göstergeleri olarak kabullendirmede aktif rol oynar. Dolayısıyla anlamın ve tarihin değişken, çelişkili, gerçek deneyimden ziyade medya tarafindan üretilen ürünlerden oluşturulduğu, gerçekliği bir gösterge olarak tükettiğimiz, gerçekliği tam anlamıyla bir inkar içinde kendimizi göstergelerle kuşatmış olarak yaşadığımız bir ortamda olduğumuz söylenebilir (Baudrillard, 2005).

Lyotard modern toplumu biçimlendiren söylemlerin büyük anlatılara dayalı olduğunu vurgular; büyük anlatı örneğine bilginin yegane kaynağının bilim olduğu söylemi de dahildir (Malpas, 2003). Lyotard büyük anlatıların her inanç sisteminde ve ideolojide bulunduğunu, modern toplumun tüm hallerinin büyük anlatılara dayalı olduğunu öne sürer. Lyotard, post-modern kültürümüzde kullanılan kitle iletişim araçları ne olursa olsun ya da spekülatif anlatı veya özgürlük anlatısı olsun ya da olmasın, büyük anlatının güvenirliğini yitirdiğini varsayar (Browning, 2000). Bunun nedeninin, İkinci Dünya Savaş sonrası dönemden itibaren vurguyu eylemin amacından aracına kaydıran yöntem ve teknolojilerin ortaya çıkması olduğunu ileri sürmektedir (Lyotard, \& Engelmann, 1986). Kamu alanının şekillenmesinde anlatının oynadığı rolü anlamak için üst anlatı ile büyük anlatı arasındaki farklılıkları belirlemek gerekir. Lyotard'a göre spekülatif anlatı ve özgürlük anlatısı olmak üzere iki tür modern büyük anlatı tanımı vardır (Browning, 2003, s. 232). Büyük spekülatif anlatının temel fikrine göre insan yaşamı veya Hegel'in de dediği gibi "Ruh" bilgisini artırarak gelişim göstermektedir. Bu spekülatif anlatının gerekçesi, Hegel'in gerçek bir bütündür ve bu, herhangi bir ifadenin veya kelime oyununun doğruluğunun veya yanlışlığının, bilgi bütününe olan ilişkisine göre belirlenmesi demektir savından ortaya çıkmaktadır. Dolayısıyla, bu bilgi bütününün büyük spekülatif anlatı olduğu sonucuna varılır (Browning, 2003, s. 234). Büyük özgürlük anlatısı, son birkaç yüzyılda çeşitli şekillerde tezahür etmiştir. Aydınlanma Çağında doktrin, kör inanç ve batıl inanç yerine muhakeme, mantık, eleştirme ve düşünce özgürlüğüne vurgu yaparak insanların 
hayatlarını kısıtlayan ve rahiplere güç tanıyan batıl inançlardan insanları özgürleştirme fikrine odaklanmıştır (Cohen, 2010). Bunun Marksist versiyonu da, patronları tarafından sömürülmekten işçileri kurtarmaya ve kendi yaşamlarını kontrol altına alabilmeleri için gerekli becerilerin geliştirilmesine odaklanmıştır. Marksizmin büyük anlatısında, kapitalizmin çökeceği ve ütopik bir sosyal dünyaya evrileceği inancı yer almaktadır (Malpas, \& McGowan, 2002, s. 51). Bu tür büyük anlatının amacı, aydınlanan insanlığın doktrinden, mistisizmden, sömürgeden ve ıstıraptan özgürleştirilmesidir. Tarihsel bakış açısına göre, Lyotard, günümüz tarihini post-modern çağ olarak tanımlamayı haklı görmektedir. Bunun sebebi, İkinci Dünya Savaşından itibaren her türlü bilgiye ilişkin bir meşrulaştırma krizinin ortaya çıkarak, söylemlerin ruh diyalektiği, anlamın yorumbilimi, mantığın veya işlenen konunun özgürleştirilmesi veya zenginliğin ortaya çıkarılması gibi bazı büyük anlatılara ilişkin açık çağrı tarafından meşrulaştırılmasını imkansız kılmasıdır (Habermas, 1988). Dolayısıyla Lyotard, öz meşrulaştırma söylemlerini "modern” olarak adlandırmakta ve "post-modern durumu" meşrulaştırma krizi olarak tanımlamaktadır (Denzin, 1986). Bunu, Foucault'nun aydınlanmanın ilerleme anlamına gelmediğini fakat salt bir başka güç ve bilgi vasıtası olduğunu belirttiği savında da görebiliriz (Poster, 1984). Foucault, insanoğlunun Batı'nın ilerlemesi olarak adlandırdığı şeyin aslında bir başka hakimiyet ve kontrol şekli olduğunu ve bir gerçeklik deneyimimizi bir başkasıyla yani bir tür güç olan bilgi ve doğru ile değiştirdiğimizi öne sürdüğü kuramıyla bilinir (Habermas, \& Levin, 1982). Lyotard, modern toplumlarda bütünselliğin, söz konusu toplumların teamüllerini ve inançlarını ifade eden büyük anlatılar yoluyla sağlandığını öne sürer. Her bir inanç sisteminde veya ideolojide en az bir büyük anlatı bulunmaktadır. Modern toplumlar her bakımdan bu büyük anlatılara bağlıdır. Büyük anlatılar, heterojenliği düzenli toplumlar haline getiren, diğer evrensel ilkeler ve genel hedefler adı altında başka söylemleri ve sesleri susturan ve dışlayan homojenleştirici güç olarak ve aynı zamanda sosyal düzenlerin istikrarsızlığını bir gizleme yolu olarak, içerme ve dışlama yoluyla işler (Smith, 2006, s. 65).

"Hiper" kelimesi, genel olarak olağan derecenin ötesine ulaşan veya belirli bir normun ötesinde yer alan anlamını taşır. Diğer yandan gerçeklik, kendisi ile ilişkilendirilen daha karmaşık bir anlam ağından oluşmaktadır ve kopyası veya taklidi olan bir şeyle (liman imgesi) karşılaştırıldığında, var olan bir şeye (gemilerin yük almalarına ya da yük boşaltmalarına, yolcu indirip bindirmelerine uygun kuruluşları bulunan, barınmalarına yarayan doğal ya da yapay sığınak) ilişkin algıya yönelik nesnel bir somutluğu olan şeye (fiziksel olarak liman) kadar uzanır. Anlamsal olarak bu kelimelerin birleştirilmesi, toplumun gerçek olarak bildiği, yani gerçeklik olarak görülen ve anlaşılan imgesel varlığın ötesine uzanan bir tür gerçeklik anlamına gelen hipergerçeklik fikrini beraberinde getirir. Sonuç olarak, hipergerçekliğin anlaşılması faydalıdır çünkü insanların, ürünler hakkında makul bir şekilde gerçekmiş gibi sonuca varması, algılaması ve kabul etmesi yollarının anlaşılmasını sağlar. Hipergerçekliğin göze çarpan özelliklerinin, bu özelliklerin metinlerde nasıl tezahür ettiğinin ve hipergerçekliğin teknik iletişimde hem üretim hem de tüketim anlatılarını nasıl etkilediğinin anlaşılması, kuram ve uygulama arasında bir köprü sunar. Görsel anlatı ve kültürün mesleki alanlarda daha da yaygınlaşmasıyla birlikte söz konusu ürünlerin etkileşimsel ve retoriksel niteliğinin anlaşılması, sözbilimci cephanesi için önemli bir beceridir ve medya okuryazarlığının artırılmasında da önemli 
bir rol oynamaktadır. Hipergerçeklik, akademide kullanılan yaygın bir terimdir fakat kamunun hipergerçekliğe ilişkin anlayışı, bunun nasıl işlediği ve sözbilimsel durumla olan ilişskisi hala yeterince gelişmemiştir. Bu bakış açısı, hipergerçekliği, medyanın toplumun kimlik ve gerçeklik anlayışı üzerindeki etkisini vurgulayarak gerçeğin inşasını eleştirel, stratejik ve sözbilimsel olarak inceleyen post-modern perspektiften sunacaktır. Ayrıca, gazeteciliğin geleceği olarak ifade edilen mekânsal gazetecilik örneği üzerinden hakikatın inşasını konu alıp yeni teknolojilerin hiper ortam üzerinden nasıl "gerçeği" inşaa ettiklerini eleştirel bir dille yansitacaktır.

\section{Dolaylı Temsiller}

Çağdaş medyanın ve teknolojinin insan deneyimleri üzerindeki etkisini çalışmış olan ünlü Fransız kültür kuramcısı Jean Baudrillard, Henri Lefebvre, Roland Barthes ve Pierre Bourdieu'nun yönlendirmesiyle kendini Marksist siyasal ekonominin bir muhalifi olarak konumlandırmıştır, fakat zamanla, medyanın ve teknolojinin kendini dünyanın gerçek bölgesinden ve dolayısıyla da söz konusu dünyada yaşayan insanoğlundan uzaklaştırdığını ileri süren bir Neo-Marksist yaklaşıma kaymıştır (Kellner, 1989). Baudrillard, gerçekliğin temsilleriyle ve simülasyonlarıyla yönetilen bir dünyada hipergerçekliği (gerçek ötesi), hakikatın ötesinde bulunan gerçeklik ve var olma algısı olarak tanımlar ve bunun doğru ile yanlış arasındaki çizgiyi bulanıklaştırdığını ileri sürer (Smith, 2015, s. 162). Bu şekilde tüketiciler, medyanın insanların gerçek olarak algıladığı şeyleri şekillendirdiği ve filtrelediği teknoloji ile yönetilen toplumda gerçeklik ile fanteziyi ayırt edemez. Kısacası hipergerçeklik, gerçekliğe dayanmayan bir şeyin varlığına inanmaktır. Gerçek olanın metaforik olarak yok edilmesiyle hipergerçeklik, kendi yerinde varlığını devam ettirebilmek için yeni bir simüle edilmiş gerçekliği inşa eder (Baudrillard, 1994, p.6). Bu yeni gerçeklik, tabiatı gereği yapaydır ve sanal yolla ve medya araçlarıyla tüketilir. Hipergerçeklik, sorgulanması gereken gerçekliğe ilişkin anlayışımızı oluşturan karmaşık temsiller sistemini anlamaya yönelik kuramsal bir çerçevedir. Hipergerçeklik, modellerin gerçeğin yerine geçtiği bir durumdur (Best, \& Kellner, 1991, s.119). Simülasyonlar, gerçeklik oluşturur ve insanlar, gerçekliği kopyalarından ayırt edemez. Bir diğer deyişle, sahte kopyalar özgün olarak bildiğimiz gerçekliğe dönüşür. Hem temsil hem de gerçeklik, (orijinali olmayan kopyalar olarak tanımlanan) simülarklarla değiştirilmiştir (Baudrillard, 1983, s. 448). Baudrillard'a göre göstergebilimsel gerçeklik hipergerçekliğe dönüşür. Hipergerçeklik özün imgeleminin ve var olanın gerçekliğinin, bir kimliğin simülarkını oluşturacak derecede bir araya geldiği, imge ile gerçeklik arasındaki diyalektik ilişkidir (Baudrillard,1975, s.25).

Dolaylı temsiller göstergelerden inşa edilir. Göstergelerin temsil ettikleri ve/veya ne anlama geldikleri ile ilişkili olarak bunların karmaşasının anlaşılması, kendilerini ifade etmek için kullandıkları teknolojik araçlardan dolayı daha da karmaşık hale gelmiştir. Dolaylı iletişim; hipergerçekliği kod haline getirir, dağıtır ve bunun varlığını mümkün hale getirir. Kitap, magazin, televizyon, film, internet gibi her türlü kitle iletişim arac1, hipergerçekliğin kendini kullanıcıların algısal süreçlerinde tezahür ettiği bir yöntem halini alır. İmgeler, gittikçe daha da kapsayıcı hale gelen teknolojiler sayesinde kodlanabilir 
ve deşifre edilebilir; düzenlenebilir ve değiştirilebilir; yeniden üretilebilir ve yeniden yayınlanabilir.

Baudrillard, kendi düşüncesini geliştirirken üç düzeyde simülarktan bahsetmiştir: sahtesi, üretim ve simülasyon. Baudrillard'ın simülark türleri; gerçekliğin yansıtılmasını, gerçekliğin örtülmesini, gerçekliğin yokluğunun maskelenmesini ve son olarak simülarka (hipergerçeklik) dönüşmesini kapsar (Baudrillard, 1994, s. 32). 1) Baudrillard'ın modern öncesi dönem ile ilişkilendirdiği ilk simülark türünde imge, gerçek olanın bariz bir taklididir. 2) Baudrillard'ın on dokuzuncu yüzyılın endüstri devrimi ile ilişkilendirdiği ikinci simülark türünde seri üretimden ve kopyaların yaygınlaşmasından dolayı imge ile temsil arasındaki farklılıklar gittikçe yok olmaya başlar. Söz konusu üretim, temelinde olan gerçekliği o kadar iyi taklit eder ki bu gerçekliği saptırır ve örter; ancak eleştirel veya etkili bir siyasi eylemle saklanan bu gerçekliğe ulaşmanın hala mümkün olduğuna dair bir inanç söz konusudur. 3) Post-modern çağ ile ilişkilendirilen üçüncü simülark türünde ise temsilin gerçekliğe üstün geldiği ve gerçekliği belirlediği kesin bir simülark ile karşı karşıya geliyoruz. Artık gerçeklik ile onun temsili arasında bir farklılık yok ve sadece simülark vardır. Her şey, bir simülasyon olarak tezahür etmek zorunda. Manzaralar fotoğraf olarak, kadınlar cinsel bir senaryo olarak, düşünceler bir yazı olarak, terörizm bir moda olarak ve medya ve olaylar televizyon olarak tezahür eder (Baudrillard, 1994, s. 32).

\section{Büyük Anlatı}

Retoriğe ilişkin birçok modern kuram, insanların gerçeklik olarak bildiği şeylerin hepsi olmasa da birçoğunun retoriksel olarak inşa edildiği varsayımına dayanmaktadır" (Potter,1996, s. 98). Retoriksel eylemin ikna edebilme gücü vardır. Gerçeklik algılarının retoriksel inşalar tarafından yönlendirildiğini söyleyebiliriz. Gerçeklik algıları, gerçekliği gördüğümüz ortamlar tarafından yönlendirilir. Eski Yunan döneminde retorik, bilinmeyenle ilgili söylencelerin ve efsanelerin üretilerek bilinmeyenin anlaşılması için kullanılan bir araç haline gelmiştir. Eski Yunanlılar, kadim retoriğin amacının, dilin sahip olduğu gücü dağıtmak olduğunun farkına varan ilk medeniyet olmuştur (Smith, 2016). Bu güç, kendini sözlü gelenekle var etmiş ve siyasi ortamlarda, yargı sisteminde ve törenlerde tezahür etmiştir. Kaçınılmaz olarak Yunan kültürü Romalılara ve sonra, Roma kültürü de Orta Çağ Hristiyanlarına düşmüştür. Orta Çağın sosyo-politik ekonomisi, retoriği hükmeden sınıfa yönelik bir tehdit olarak görmüş ve retoriğin küme düşerek kilise doktrinine indirgenmesine neden olmuştur (Smith, 2016). Dini dogma yerini Rönesansın doğuşuna bıraktığında, retorik, yeniden değişim geçirerek içerik ve kelimeden ziyade sunum ve şekle odaklanan söylenen söze dönüşmüştür. Modern retorik, sözlü ve yazılı kelimeleri bir araya getirmekle kalmamış, aynı zamanda retoriği bir imge olarak ortaya koymuştur (Barthes, 1977, s. 142).

Retorik; katılımcıların, yaratıcı ile hedef kitle arasında bir köprü oluşturmak için gösterge sistemlerini kullanarak ortak bir paydada anlam oluşturmak için sembolleri kullandığı ortaklaşa inşa edilen bir gerçeklik olarak bilinir. Hipergerçeklik deneyiminin etkili olabilmesi için katılım önemli bir unsur olduğundan ve okuyucunun, anlamın 
oluşturulmasına aktif olarak dahil olması gerektiğinden bunun gerçekleştirilmesi hayatidir. Konuşma, metin veya görsel olarak olsun ya da olmasın retorik, anlamı eleştirel olarak değerlendirmek ve iletmek için ortak bir anlayışın ve diyalogun olduğu ortak olarak paylaşılan bir ortam inşa etmeyi amaçlar. İnanılırlık kavramı, belirli bir retoriksel olayın veya savın iletilmesinde önemli bir unsurdur. Retorik üzerinden iknanın inşası, bir konunun gerçeğe çok yakın bir şekilde sunularak konunun kabul edilme ve gerekirse ilgili kitleyi harekete geçirme sanatı olarak kabul edilir ve sonrasında alıcı davranışı ise, sorgulanabilirliğe ve inanılırlığa tabi retoriksel aracın hitabetçi tarafından ustalıkla yönlendirildiği inancına bağlıdır (Bevilacqua, 1965, s.42). Tarih boyunca metaforlar, temsillerin ve ilgili kavramların inşa edilmesi amacıyla retoriksel araç olarak kullanılmıştır. Dolaylı araçların kullanıldığı bu çağ, yeni fikirlerin, yerlerin, şeylerin, insanların, akla gelebilecek her şeyin görsel temsilleri için metaforun dönüştürülmesi becerisini de beraberinde getirmiştir. Hipergerçekliğin yazarlarını yeni temsiller bulması için harekete geçiren fikir işte budur. Bazıları için de görsel retorik, bu gerçekçi ve inanılabilir aracı sağlayabilir.

Güdülenme, kısmen özdeşleştirme aracılığıyla tezahür eder. Bir kişiyi konuşma, jest, tonlama, dizin, imge, davranış, fikir yoluyla o kişinin dilini konuşabildiğiniz ve onunla ortak noktalar bulabildiğiniz kadarıyla onu ikna edebiliriz. Retorik belirli bir durumdan tezahür eder. Retoriğin tamamen durumsal olduğunu ve tepki olarak uygun söylem yarattığını ifade edebiliriz (Cheney, 1983, s. 144). Alternatif olarak, söylemin retoriksel bir durumu ifade ettiğini öne sürmek mümkündür (d'Angelo, 1975). Retoriksel durum üç unsuru kapsar. Bu unsurlar şunlardır: gereklilik (yapılması veya değiştirilmesi gereken bir şey), hedef kitle (değişim unsuru olabilecek veya değişebilecek olan kişiler) ve kısıtlar (karar verme sürecini ya da eylemi kısıtlama gücüne haiz olan şey veya kişi) (Vatz, 1973, s. 155). Retoriksel gerekliliğin oluşturuldukları zaman içerisinde var olan sosyal sorunlara ve temalara dayandığ 1 ileri sürülmektedir (Cheney, 1983, s. 159) ve olaydan önce değil de, iletişim kuran kişinin retoriksel seçimleri tarafından kısmen retoriksel olarak oluşturulduğuna inanılır. Durumlar, niteliklerini, kendileri etrafinda bulunan veya onları oluşturan retorikten alır. Diğer bir deyişle, retorik değişim unsurlarını oluşturabilmek için bir gereklilik (dikkate sunulması gereken bir sorun) algısı yaratır. Hayattaki gerçek olaylara (geçmişte ya da günümüzde) benzer, kişilerde yankı uyandıran, muhtemelen kişilerin belirli bir şekilde düşünmesine veya hareket etmesine neden olan anlatıdır. Bu hipergerçeklik değildir de nedir?

Retorikçiler, okuyucuları ikna etmek amacıyla uygun göstergesel taktikler seçer dolayısıyla, tüketiciler bilinçli ya da bilinçsiz olarak genel eserin inanılabilirliğine karar vermek amaciyla uygulanan görsel taktiklere göre eseri değerlendirir. Bu, görsel yöntemlere ve bu yöntemlerin retoriksel açıdan etkililiğinin değerlendirilmesine dayanan ortak inşa edilen bir süreçtir. Aktaran kişi, gerçekliğin parçalarını indirgemeci bir süreç aracılığıyla sunduğundan, okuyucular, buna ek bir süreç olarak yaklaşır. Bu süreçte, yeterince görsel ipucunun verilmesi durumunda okuyucular, hikayeyi tamamlamak için eksik olan yerleri kendileri doldurur. Diğer bir deyişle, bir anlatıyı gerçekleştirenin ortak olarak inşa edilen retoriksel stratejisine karar verme süreci okuyucuların kendi deneyimlerini kullanarak makuliyetini değerlendirmesine neden olur. Diğer bir deyişle, hedef kitle, sunulan şeyi kabul etmeye ya da reddetmeye karar vermek için retoriksel değişkenlere tepki verir. 
Örneğin, halihazırda var olan kümeden onları ayırt etmenin yanı sıra insanların bunları belirli bir türe (örn., siyahiler, asyalılar, vb.) ait olduğunu kabul ettikleri bu karakterlerin standart yapılagelişlere bağlı kalması gerekmektedir. İmge gücünü kendi doğruluğundan, gerçeklik ile olan bağlantısından alır.

Retorik aracılığıyla özdeşleştirme ethos, pathos ve logos yoluyla oluşturulur (Braet, 1992). Ethos, "karakter" anlamına gelen Yunanca bir sözcüktür. İkna edici dil açısından otoriteye ve güvenirliğe hitap eder. Ethos, hedef kitleyi ilgili konuşmacının veya yazarın güvenilir bir kişilik olduğuna veya savın güvenilir olduğuna ikna etme aracıdır. Önemli bir ikna etme aracıdır çünkü hedef kitlenizin sizi (veya savınızı) güvenilir ve dürüst bir kişi olarak görmesini sağlayabilirseniz onları ikna etmeniz çok daha kolay olacaktır. Pathos, "1stırap" veya "deneyim" anlamına gelen Yunanca bir sözcüktür ve hedef kitlenin duygularına hitap olarak ikna edici konuşmalarda kullanılır. Pathos, hedef kitlede veya okuyucuda duygusal bir tepki uyandırarak ikna edici bir sav oluşturma yoludur. Hedef kitlenin umutlarına ve hayallerine hitap ederek, onların korkularına veya endişelerine oynayarak veya onların belirli inançlarına veya ideallerine hitap ederek ikna ederken pathosu kullanabilirsiniz. Logos, "kelime" veya "muhakeme" anlamına gelen Yunanca bir sözcüktür. Retorikte mantığa ve muhakemeye hitap eder. Hedef kitleyi mantıksal düşünce, gerçek olgular ve akılcılık ile ikna etmede kullanılır. Logos, faydalı bir ikna etme aracı olabilir çünkü bir savı mantıksal ve sağlam bir muhakemeyle "kanıtlayabilirseniz" hedef kitlenizin ikna olması daha muhtemeldir. Lyotard, insanların veya hedef kitlenin inanma gücünün anlatıların gerçekleştirilmesi veya "gerçek" hale getirilme sürecinde önemli olduğunu ifade eder (Ambrose, 2009, s. 636). Bir bakıma insanlar, anlatıları gerçekleştiren salt unsurlardır: anlatıları sadece yeniden ifade ederek değil aynı zamanda bunları dinleyerek ve anlatılar aracılığıyla kendilerini ifade ederek bunu gerçekleştirir. Diğer bir deyişle, kendilerini okuyucu veya dinleyici konumunun ve anlatıcı öykünün yanı sıra anlatıcı konumuna da koyarak anlatıları kendi deneyimlerine sunarlar (Ambrose, 2009, s. 636).

\section{Gösterme Süreci}

Göstergebilim, çok çeşitli türlerde göstergelerin çeşitli kanallar ve iletişim araçları aracılığgyla aktarıldığı ve sosyal açıdan düzenlenmiş ve evrimsel olarak üretilmiş gösterge sistemlerinden ve anlamlama veya gösterme sürecinin durumlarından (göstergelerden anlam çıkarma süreçleri gibi) oluşan geniş bir yelpazeye sahip bilim dalıdır. Baudrillard, gücün göstergelerin oluşturulması ve yer değiştirmesi ile aktarıldığ1 bu gösterme sürecinde sembolik değişimi başlangıç noktası olarak görmüştür (Kellner, 1989, s. 291). Hipergerçeklik, sosyal ilişkilerin ve hiyerarşilerin sürdürüldüğü ve düzenlendiği bir değişim türü olan sembolik değişim fikrine dayanmaktadır. Dolayısıyla bu, sembolik bir karşılıklı güç değişimidir. Gerçekliğin kültürel algısı, tezahür ettiği ve üretildiği bağlam içerisinde somutlaştırılır. Bu, en güçlü sosyalleşme türüdür (Merrin, 2005, s. 53). Medya, Baudrillard'ın hipergerçekliğinin en baskın çıkış yerlerinden biri olmuştur. Baudrillard'a göre hipergerçeklik, medyanın büyük ölçüde gördüğümüz şeyleri şekillendirdiği ve filtrelediği ve özgün gerçekliğin aracılı gerçeklik yani hipergerçeklik ile değiştirildiği, 
teknolojik açıdan zengin bir toplumda tezahür eder. Göstergeler, göndergesel bir boyuta değil, yalnızca birbirine hitap eder (Baudrillard, 2019, s.50). Efsane olarak hipergerçeklik, hiçbir şeyi saklamaz veya hiçbir şeyi gözler önüne sermez: hipergerçeklik başka bir anlam yükler; efsane, ne bir yalan ne de bir itiraftır: efsane bir bütündür (Barthes, 1972).

Tabiatı gereği, insanlar sembol kullanan ve sembol tüketen retoriksel varlıklardır (Burke, 1966, s. 3). Bu içgüdüsel eylem, yaşadığımız dünyanın bilgilerini toplama ve saklama, diğer bilgilerin kullanılma veya bilinmeyenin getirdiği uyumsuzluktan kaçınma yollarını kapsar. Göstergebilim, bize izleyicilerin göstergelerden, nesnelerden ve metinlerden anlamlar ürettiğini ve anlamların, bu unsurlar içerisinde sabit olmadığını gösterir. Diğer bir deyişle göstergebilim, oluşturuldukları zaman içerisinde var olan sosyal sorunlara ve temalara dayanır. Bu sabit olmayan rastlantısal (kavramsal, kolektif) anlamlar, algılanan şeyin bireysel açıdan anlaşılmasına olanak sağlar. İzleyiciler, sadece dünyaya bakmayı değil aynı zamanda onu anlamayı da ister. Ancak bakmak ile görmek aynı şey değildir: bakmak, gözlerin biyolojik bir işlevi iken, görmek anlamı bilişsel olarak idrak etmektir. $\mathrm{Bu}$, insan unsurunun bir parçasıdır: Gerçeği anlamayı ve kavramayı ve bütünselliği anlamayı isteriz çünkü bu tabiatımızın gereğidir. Bu fotoğraflarda, sinema filmlerinde ve televizyonda da söz konusudur. Uzun zamandır entelektüel çevreler; göstergelerden anlamın oluşturulma sürecini anlama, göstergelerin göndergelere nasıl bağlı olduğu ve göstergelerin, göstergeleri alan kişilerde nasıl yorumlama veya tepki verme süreçlerine neden olduğu konularıyla ilgilenmiştir (Eco, 1979).

\section{Dil}

Yeni gerçekliğin (hipergerçekliğin) tezahür ettiği araçlardan biri de dildir. Dil, anlamı ve bilgiyi inşa ettiğinden çevremizdeki dünyayı anlama araçlarını da inşa eder. $\mathrm{Bu}$, belirleyicilik kuramına (düşünme şeklimizin kullandığımız dil tarafından şekillendirilmesi) ve farklı kültürel gruplara ait kişilerin neden dili farklı olarak anladığını açıklayan dilsel görecelik kuramına (dünya görüşümüzün dil seçimlerimizi etkilemesi) dayanmaktadır (Kant, 1929). Bu, bir kültürün dünya görüşünü anlamanın yollarından birinin dilsel etkileşim olduğu savında da aşikardır.

Post-modern toplumda dil şeffaftır ve dolayısıyla, kelimeler sadece işlevi olmayan temsiller olarak iş görür (Lyotard, 2000). Bu inşa, görünüşe göre olası bir gerçeklikte inşa sürecinin bir parçasıdır. Dil, taraflar arasında anlamın aktarılmasında kullanılan belirli kültürel araçlar ve inşalar demektir. Görselleştirilmiş metin, bir dilin imgesel temsilleri (kelimeler, diyalog, telaffuzlar, sözsüz iletişim ve diğer dilsel araçlar aracılığıyla) demektir. Diğer bir deyişle, metin kişiler tarafından kullanılan dili imgeleyen/gösteren, anlama ilişkin göstergesel bir ipucu olarak işlev görür. Ferdinand de Saussure ve Amerikalı filozof Charles S. Peirce, göstergelerin hem oluşumunu hem de yorumlanmasını destekleyen yapıları anlamak amacıyla bağımsız bir araştırma alanı çerçevesini oluşturan öncüler olmuştur. Saussure, gösterge ile gösterilen arasındaki bağlantıyı insanoğlunun ve/veya toplumların isteğinde oluşturduğu rastlantısal bir bağlantı olarak görmüş̧ür (2006). Saussure, bu konuya değinmek amacıyla "gövdesi olmayan, çok çatallı dalları ve seyrek yaprakları olan bodur ağaçsı bir bitkiyi” tanımlamak için farklı dillerde farklı ifadelerin (Türkçe'de “çalı” denirken İngilizce'de “bush” denmesi gibi) kullanılmasında herhangi 
bir nedenin olmadığını ileri sürmüştür. Aslına bakılırsa iyi oluşturulmuş herhangi bir gösteren, her iki dilde de kullanılabilirdi. İyi oluşturulmuş bir gösteren, ilgili olduğu kodun imla, sesbilimsel ve diğer yapı özelliklerine uygundur ("çalı" kelimesi Türkçe'de iyi oluşturulmuş bir gösteren iken "çagi” iyi oluşturulmamış bir gösterendir).Peirce, göstereni temsilin kendisini fiziksel stratejisinde (bazı göndergesel amaçlar için seslerin kullanımı, el hareketleri, vb.) doğal olarak var olan bir form olan representamen (tam anlamiyla temsili yapan şey) olarak tanımlamıştır. Peirce, nesneyi, oluştuğu bağlam (gerçek dünya) içerisinden çıkarılmış bir varlık olan gönderge olarak tanımlamıştır (Morris, 2014). Peirce, bir göstergeden elde edilen anlamı yorumlayıcı olarak tanımlayarak, tabiri caizse göstergeyi kullanan kişinin göstergenin sosyal, bağlamsal ve kişisel açıdan ne anlama geldiğini değerlendirdiği veya buna tepki verdiği bir çeşit "müzakereye" neden olduğunu ileri sürmüştür (Morris, 2014). Böylece göstergeyi başka bir anlama gelen herhangi bir şey olarak anlarız. Görselden fiziksele kadar göstergeler anlam taşır. Ancak Baudrillard, simülasyonun kendi göndergesel sürecini inşa ettiğini ileri sürer (Merrin, 2005). Gönderge ve gönderme, tek bir şey halini alır ve anlam, temsilin kendi içerisinde kaybolur. Kimlik, çok çeşitli kopyalardan (gerçek olmayandan) oluşmuş bölünmüş gerçekliğe bağlıdır. Baudrillard'ın üçüncü simülarkı (hipergerçeklik), başlangıç noktası olmayan modeller üretir: Medya uygulamaları, gerçekliği yansıtmaktan ziyade gerçeklik halini alır. Üretilen temsiller göstergelerden inşa edilir. "Gösterge, ürettiği veya değiştirdiği fikir için bir anlam ifade eder. Ya da zihnin sahip olmadığı bir şeyi zihne ileten bir araçtır” (Baudrillard, 1994, sayfa 32).

Göstergeler; simgeler (imgenin temsil ettiği şeyle doğrudan bir ilişkisi vardır), dizin (imgenin temsil ettiği şeyle nedensel bir ilişkisi vardır) ve semboller (imgenin temsil ettiği şeyle hiçbir ilişkisi yoktur) aracılığıyla işlerler (Eco,1979). Bu bakış açısından bakıldığında görsel anlatılar, genelde simgelerin görsel metaforlar haline geldiği simgesel ürünler olarak tasvir edilir. Aslına bakılırsa metin, bir şeyi iletmek amacıyla göstergelerin belirli bir şekilde bir arada dokuma işidir $($ Eco,1979). Metinleri oluşturan göstergeler belirli kodlara aittir. Bunlar, dizisel ve dizimsel ilişkiler ile bir arada tutulan gösterge sistemleri olarak tanımlanabilir. Dizisel (kes - pes-hes) ve dizimsel özellikler taşıdığından dilin de bir kodu vardır (Fawcett, 2000). Elbette, belirli türlerde metinle oluşturmak için de kullanılabilir: örneğin; konuşmalar, romanlar, şiirler, vb. Görünen o ki alıcı, metnin oluşturulduğu kodu (kodları) bilmediği ve metin belirli bir bağlama işaret etmediği veya bağlamda tezahür etmediği sürece metnin bir anlamı yoktur. Göstergenin veya metnin kullanıldığı veya tezahür ettiği fiziksel, psikolojik ve sosyal çevre bağlamdır (Fawcett, 2000).

Daha açık düşünmemize, daha ihtişamlı yazmamıza ve daha mantıklı tasarlamamıza yardımcı olması için retorik kullanırız. Retorik, hem daha anlaşılır olması için fikirlerimizi bir düzene koymamıza hem de görsel ve sözel nesnelere ilişkin eleştirel gözlemlerimizi yapılandırmamıza yardımcı olur. Hem ikna edebilen metinler olarak hem de kitlelerin harekete geçtiği sembolik kodlar olarak görsel retoriğin anlaş1lması, görsel dünyamızın etkisi konusunda eleştirel olarak düşünme kabiliyetimizi artırır. 


\section{Kültür}

Yeni gerçekliğin tezahür ettiği araçlardan biri de kültürdür. Göstergebilimin temel amacı, bir türün göstergeleri oluşturma ve anlama kabiliyetini ve insanoğlu söz konusu ise bu kabiliyetin insanoğluna tanıdığı bilgi üretme faaliyetini anlamaktır. Daha önce bahsedildiği gibi, göstergeleri oluşturma ve anlama kabiliyeti gösterme süreci olarak bilinirken, ikincisi yani bilgi üretme faaliyeti ise temsilleştirme olarak bilinmektedir (Eco, 1979, s. 305). Temsilleştirme; dünyayı irdelemek, sınıflandırmak ve dolayısıyla bilmek amacıyla göstergelerin bilinçli olarak kullanılmasıdır. Gösterme süreci; basit fizyolojik işaretlerden oldukça karmaşı sembolizm ortaya koyan işaretlere kadar göstergelerin inşa edilmesinin ve anlaşılmasının temelinde yatan biyolojik kabiliyet anlamına gelir. İnsan zihni ve sosyal yaşamı; göstergelerin ve temsillerin inşa edilmesine, kullanılmasına ve aktarılmasına bağlıdır. Jestlerimizi kullanırken, konuşurken, yazarken, okurken, televizyon programı izlerken, müzik dinlerken, bir resme bakarken göstergeye dayalı temsili davranışlarda bulunuruz (Jappy, 2013, s. 69). Temsilleştirme; insanoğluna bilme, amaca göre davranma, planlama, sosyalleşme ve iletişim kurma gibi var olmanın getirdiği önemli hallerle etkili bir şekilde baş etme becerisi sağlamıştır. Ancak temsili faaliyetler kültürden kültüre değiştiğinden insanların gün içerisinde kullandığı işaretler, insanların edindiği dünya görüşünde dolaylı bir taslak halini alır (Jappy, 2013, s. 62).

Bir imgenin neyi tasvir ettiğinin anlaşılması; gönderen, nesne ve alıcı arasındaki ilişkinin bir sonucudur. Göstergebilimciler, bunu gösteren (imge/sözcük/ses) ile gösterilen (anlam) arasındaki ilişki olan gösterge olarak adlandırır. Göstergebilimde, bir gösterge; gösteren, nesne tarafından gösterilenin veya nesnenin anlamının meydana getirilmesiyle, gösterge olur. Nesneler temsil ettikleri şeyler gibi göründüğünden (gösteren) ve sayfada görüldüğ̈̈nden çok daha fazlasını ifade ettiğinden (gösterilen) özellikleri abartılmış, değiştirilmiş veya türetilmiş olan dünyanın yorumlanmış veya değiştirilmiş hali ile karşı karşıya gelirsiniz (Eco, 1979). Bu sadece gerçek dişı değildir: kasti olarak belirli bir kişi veya kişiler tarafından inşa edilmiştir. Dolayısıyla hipergerçeklik, yapı(lar) ile izleyici(ler) arasında iletişimsel bir etkileşim sürecinin kullanılması olarak düşünülebilir.

Örneğin bir imge olarak kuşlar gösterilmekteyse, okuyucu, nesnenin kuşlar olduğunu anlamaktadır. Ancak okuyucunun belirli kuşları diğerlerinden ayırt edebilmesi için çeşitli kuş türlerine ait bilgiye önceden haiz olması gerekir. Burada bir göstergenin, gösteren (kuş imgesi) ile gösterilenin (temsil edilen belirli bir tür kuşun bilinmesi) bir ürünü halini aldığını görüyorsunuz. Okuyucu, varsayımlarda bulunurken kuşların boyutu, rengi ve resmin bağlamı gibi görsel ipuçlarına bakabilir. Roland Barthes'in kodlar olarak adlandırdığ 1 bu kurallar, resmin anlatısını oluşturur (1977, s. 144). Barthes, birden fazla kodun izleyicilerin bir imgenin anlamına dair mantıklı varsayımlar yapmasına olanak tanıyarak bir çağrışım zinciri oluşturduğunu da iddia eder. Bir imge yani ağaçtaki kuşların resmi ne kadar karmaşık ise kişinin anlatıyı anlayabilmesi için daha çok kodu yorumlaması gerekir. Bir imge ne kadar belirsiz ise imgenin anlamını deşifre etmek de o kadar zordur. Anlatı geleneği, üç aşamadan oluşan yeterliliği tanımlayan kriterlerin de geleneğidir. Toplumun kendi ve çevre ile olan ilişkisini ortaya koyan bu üç aşamalı yeterlilik şunlardır: yöntem bilgisi, konuşma becerisi ve duyma becerisi. Bu anlatılar aracılığıyla aktarılan şeyler, sosyal bağı oluşturan pragmatik kurallar dizisidir (Ellis, 1995). 


\section{Görsel Kültürr}

Her ne kadar toplumdan ayrı bireyler olmak için çaba sarf etsek de insanlar içinde var oldukları kültürlerin ürünüdür. Kimlik, bağlı olduğumuz ve ürettiğimiz sosyal normlarla ve anlatılarla kuşatılmıştır. Bu noktada analizde karşımıza hipergerçekliğin bir başka özelliği çıkıyor: Hipergerçeklik, içinde üretildiği bağlamın bir sonucu olarak vuku bulan bir gösterge sistemidir (Smith, 2001). Kültürler, sınır olarak işlev gören kendi gösterge sistemlerini oluşturur. Kültür sistemleri; aile, arkadaşlar, duygusal ilişkiler, mesleki ilişkiler, vb. gibi diğer katılımcılar ile her düzeyde kurulan etkileşimlerdir. İnsanlar; her birinin kendi kuralları, yönlendirici ilkeleri, göstergeleri ve kodları olan çeşitli sistemleri kullanır. Kültür; bir toplum içerisinde gerçekleştirilen çok çeşitli faaliyetlerden belirli bir sosyal grup tarafindan oluşturulan bir düşler ve anlamlar topluluğuna kadar geniş yelpazede anlamlar içerir (Gottdiener, 1985). Dil yapılarının derinliği ve kapsamı göz önünde bulundurulduğunda kültürel bilgi, günümüzde bizi çevreleyen aracılı kültürle birlikte daha önce hiç olmadığı kadar çok sorgulanmaktadır.

Görsel kültür, izleyicilerin yapay ürünleri nasıl yorumladığı ve anlamla donatılan bu nesnelerin izleyiciler tarafından nasıl bilindiğidir. Görsel kültür başlıca görsel aracılı formlar aracılığıyla izleme ve görme faaliyetlerinin yayılması için tasarlanmış bir dizi kültürel teknoloji tarafından her düzeyde nüfuz edilmiş bir kültür olarak tanımlanır (Evans \& Hall, 1999, s. 7). Daha basit olarak açıklamak gerekirse görsel biçimde gösterilen kültür özellikleri olarak açıklanabilir. Jenks (2002), görsel kültürü anlamlandırma süreçleri, imgelerin üretimi, sürdürülmesi ve görünür hale getirilmesi dahil olmak üzere bir dizi kültürel oluşum ile izleyicinin oluşturulması arasında var olan karmaşık etkileşim olarak tanımlar (s. 68). Görsel kültür, sadece çevreden (kültür) ibaret olmamakla birlikte aynı zamanda, bulunduğu tüm formlarda bir tüketim ve yorumlama sürecidir. İnsanların her gün telaffuz ettiği kelimeler ve yaptığ 1 eylemler gibi görsel kültürde vuku bulan imgeler, retoriksel sembollerdir. $\mathrm{Bu}$, bireyler, iletişim amaciyla görsel semboller kullandığından bireylerin ürettiği bir meta ve görsel ürünlerin iletişimi sağladığı sembolik süreçlere odaklanan ve uzmanlar tarafından kullanılan bir bakış açısı olarak ifade edilen görsel sözbilimin tanımlarında açıkça belirtilmiştir (Moriarty, 2005, ss. 229-231). Görsel sözbilimi esas olarak görsel yollarla gerçekleştirilen ve çeşitli toplumları etkilemek amacıyla bakma, görme ve çabalama gibi kültürel olarak türetilmiş yollarla manidar hale getirilen sembolik eylemler” olarak tanımlar (Moriarty, 2002, ss. 19-22).

Görsel sözbilim; hem gerçekliğe ve özgünlüğe dair anlayışımızı etkileyen bir ürün ve süreç hem de görsel dünyada var olan bir güçtür. Dolayısıyla, görsel sözbilim hipergerçekliğe dahil olur. Sosyal yaşam alanında göstergebilimi Marksist kuramla kaynaştıran göstergenin politik ekonomisinde göstergebilim ve toplum; insan ürünlerinin, medyanın ve teknolojinin toplumların içinde bulundukları dünyayı anlama şeklini doğrudan etkilediği sosyal mübadele kuramının temelini oluşturmuştur. Hipergerçeklik, belirli bir dünya görüşünü oluşturan göstergelerin karmaşık, kültürel bir sistemidir. Bu özellik, somut bir şeye ilişkin olarak hipergerçek bir olayın veya nesnenin anlaşılmasında vuku bulan göstergesel, ideolojik ve kültürel süreçleri ifade eder. Hipergerçeklik, sözbilim, göstergebilim ve kaçınılmaz olarak da imgelerin üretimini ve tüketimini kontrol eden güçtür. Ürünler, belirli bir durum sonucu ortaya çıkar; bir gösterge sistemini kullanır; 
dili ve metni kullanır; kendini var eder ve kültürlerin ve geleneklerin çeşitli özelliklerini temsil eder. Ürünler; fikirlerin, sorunların veya kavramların, nasıl gerçek dünyaya olan bir bağlantı olarak görüldüklerinin ve nasıl bilgi üretme kaynağı olarak anlaşıldıklarının okuyucular tarafından anlaşılması için bir yöntem olarak işlev görür.

\section{Băglantılar ve Anlamlılık}

Simülarklar, kendilerini kopyalar arasında bağlantılar ve anlamlılık aracılığıyla dışa vurur. Baudrillard; bireylerin tamamen yeniden yapılandırılmış bir kamusal alana dahil olmayı umarak bir çeşit kimlik ve sosyal katılım arayışına medya ve kitlesel tüketim alanlarında girdiğini ileri sürer (Gane, 2002, s. 33). Aracılı gerçeklik; karmaşık anlatıları, metni ve imgeleri birbiriyle karıştırarak gerçekçi deneyimler inşa eder. Aracılı metinler, gerçek hayatı taklit eder ve gerçekçi ve inanılır imgelerle, gerçek insanlara veya olaylara olan bağlantılarla ve tanımlanabilir göstergesel kodlar aracılığıyla neyin gerçek olup neyin olmadığına ilişkin anlayışımızı etkiler. Değişkenlerin bazıları kendiliğinden gerçekçi olmasa da tasvir edildiklerinde ve kullanıldıklarında inanılır durumda ise bir metinde derinlik sağlanabilir (Edbauer, 2005, s. 8). Ona göre hedef kitlenin yeniden kavramsallaştırılması, kitleyi yazma sürecinin bir parçası haline getirerek ortak olarak oluşturulan sözbilimsel bir olayın inşa edilmesi anlamına gelmektedir. Nihayetinde hedef kitleler, belirli bir belgede içeriğin nasıl sunulacağına büyük oranda karar veren gruptur. Bir bakıma bu, okuyucuların bir metnin sorgulanabilirliğini onaylama biçimidir. Yani okuyucular, metni kurama göre değerlendirmenin yanı sıra kendi hayat deneyimleriyle karşılaştırarak "gerçek hayatta" gerçekten kullanılıp kullanılamayacağını muhakeme eder (Canter et al., 2003, ss. 251-255). Okuyucular; diğer arac1lı ürünlerle de olduğu gibi, karakterlerle, hikayenin konusuyla, temalarla veya önemli gördükleri her türlü özelliklerle kendilerini özdeşleştirirler. Ayrıca belirli sanatçıları veya yazarları, çeşitli başlıklarla ve hikaye örgüleriyle takip ederek onlarla özdeşleşirler. Ne olursa olsun, özdeşleştirmeyle, okuyucular, takipçilere, hayranlara, vb. dönüşürler. Bir toplumun işleyebilmesi için sembolik alışveriş kural olarak kabul edilmiştir. Kabulleniş, şartlı teslim olma anlamına gelmez. Bundan ziyade belirli bir amaca ulaşabilmek için gücün toplumda oynadığı rolün anlaşılması demektir.

Tüm doğrular diyalektikten, yani söylem toplulukları içerisinde yer alan bireylerin etkileşiminden doğar (Grimaldi, 1978, s. 173). Dolayısıyla retorikçi, ürün ve hedef kitle bağlam içinde kullanılmış anlamı şekillendirir. İnanılırlık duygusunun bir başka elde edilme yolu ise asıl kişilere, yerlere ve olaylara olan özgün bağlantıların kabul görmesidir. Bir başka gerçekçilik yöntemi, bağlamı içerir, veya bütünleştirici fotoğrafların ya da tanımlanabilir yerlerin oluşturulması içeriğe yönelik gerçeklik duygusunun sağlanabildiği ortam kapsama girer (D’Angelo, 2009, ss. 31-32). Olay yerine olan aşinalık ve orada temsil edilen eylemlerin, nesnelerin ve kişilerin olağan niteliği, gerçekte orada olan şeylerin gözlemlenmesini ve dolayısıyla dünyanın düzenine ilişkin anlayışımızı doğrular. Birçok popüler eğlencede olduğu gibi özdeşleşme gerçekleştiğinde yaratıcıların; gerçekliği değiştirme, gerçeğe kurgu katma ve hâlâ bunları inanılır kılma becerisi öne çıkar. Filmlerde özgün yerlerin arka plan olarak veya tarihi kişilerin karakter olarak kullanılması; sorgunalanabilirlik, özdeşleştirme, karakterler, görsel tasarlama, olay örgüsü ve dil/diyalog açısından bir inanılırlık duygusu sağlar. 
Unutulmamalıdır ki, bir gerçeklik ancak ve ancak kendi içerisinde tutarlı önermeler bütünüdür. $\mathrm{Bu}$ görüş Pragmatik Hakikât Teorisi tarafından da desteklenmektedir. Pragmatik Hakikât Teorisine göre, gerçeklik ancak fayda ile ölçülebilir (Peirce, 1955, s. 31). Peirce, bilimsel bilginin doğruluğunu kesin olarak bilinemeyeceğini, "gerçeğin" bir bilim topluluğunun geniş çevrelerince kabul edilmiş olan çeşitli kriterleri sağlaması ve gerçeğe yaklaşan en önemli açıklamalar bütününün kabul edilmesiyle "gerçek" olarak kabul edilebileceğini vurgular (Peirce, 1955, s. 31).

\section{İletişim Türlerinde Retorik}

Retorikte ikna etme söz konusudur. Retorik; kitaplarda (bağlı metinler), sanatta (görsel tekniklerin kullanımı), resimlerde (görselleştirme), film yapımında (bakış açısı teknikleri) ve anlatılarda (hikaye anlatımı) belirgin şekilde görünür (McKerrow, 1989). Yüz yüze iletişim, en doğal iletişim şekli olarak görülürken, dijital medya araçları daha az doğal olarak görüldügünden belli bir amaç ve yöntemle oluşturulmuş aracılı ürünleri sunduğu düşünülür. Dahil edici içerik üzerine odaklanmak, tamamlayıcı detayları vurgulamak, yani önem verilmesi istenen detaylara dikkat çekmek ve diğer detayları göz ardı etmek, anlatıları bir retorik aracı haline getirir. Görsel metinler, izleyicilerin herhangi bir yere gitmesine veya bir hikaye oluşturmasına olanak tanıyan araçlar sağlayarak metafor olarak işlev görür.

Günümüzün tamamen dijital özel efektlerle donatılmış sinemaya özgü deneyimleri, hipergerçekliğin alanını genişletmektedir. Her ne kadar olayların zaman çizelgesi doğru olabilse de ekranda verilen bazı karakterler ve hikaye örgüsü kurgudan ibarettir. Kameraların neyi kayıt edip neyi etmeyeceğine, film çekiminin niteliğine, kurguya ve müziğe ilişkin her karar, kaçınılmaz olarak filmde işlenen olaya ilişkin belirli bir bakış açısına işaret eder. Hakikatı yansıttığı iddia edilen belgesellerde bile hakikat sorgulanabilir. Yönetmen, esas itibarıyla kendisinin vurgulamayı veya temsil etmeyi değer gördüğü şeyleri vurgulama veya temsil etme kapasitesini koruyarak çeşitli duyguları ve bilgileri ortaya çıkarır. Ancak bir sahnenin düzenlenmesi, bir konunun film karesine alınış biçimi, filmin son haline dahil edilen kamera görüntüsü ve bir konuya yöneltilen başlıca sorular herhangi biçimde bir belgeselin meşruluğunu değiştirebilir. Tarih, filmlerdeki gibi her zaman kesin ve mükemmel olmadığından daha geniş bir kitleye hitap edebilmek adına bir çeşit yaratıcı kontrole ihtiyaç duyulur. Orada olma eylemi, sanki izleyici olayın olduğu gün olaya tanıklık etmişçesine izleme deneyimini çok daha inanılır kılar. Eşsiz özel efektler ve tarihi sahnelerinin birinci şahıs bakış açısından görülmesi, bir izleyici deneyiminden ziyade gerçek bir tarihi olay olarak yanlış anlaşılmaya yol açacak şekilde tarihi olayların yeni bir versiyonunu inşa eder. Baudrillard, medya türlerini şöyle açıklar: "Bunlar, ekranda meydana gelen olaylardır ve gerçek olaylar değildir, şeylerin aracılık yapan hipergerçekliğinin arkasında kaybolan tarihi gerçekliğe sahip olağan gerçekliktir" (Gane, 1993, s. 146). Örneğin, bir fotoğrafın amac1, söz konusu olayı belgelemek değildir. Fotoğraf, özgünlük hissi veren fakat gerçekte o olmayan bir olayın ta kendisi olmak ister. Amaç, kullanılan söz konusu medya aracının varlığını seyirciye unutturmaktır ve seyircinin, temsil edilen nesnelerin huzurunda olduğuna ikna etmektir (Bilandzic, \& 
Busselle, 2013, s. 210). Buna, insan duyularına ait deneyimleri yeni formlarda yeniden üreten ve gerçek olarak bildiğimiz şeyler ile gerçek olduğunu bildiğimizi düşündüğümüz şeyler arasındaki duvarları yıkan hiper ortam duygusu denir ve tüm iletişim türlerinde (basın ilanı, reklam ve tanıtım çalışmaları da dahil) hiper ortamın mantığı, görsel bir alanın aracılı ortam ile aracılık etmenin ötesinde yer alan gerçek alan olarak görülmesini sağlamaktır.

Yazılı söylem, insan deneyiminin yeniden işlenebilmesi, okunabilmesi, üzerinde çalışılabilmesi ve nesne olarak kullanılabilmesi için insan deneyimini indirger ve düzenler (D'haen, 1983). Metin, konuşmanın bir simülasyonu haline gelir ve farklı formlarda kullanılabilecek ve kopyalanabilecek şekilde işlev görür. Bununla birlikte bu yeni gerçekliğin püf noktası, söz konusu gerçekliğin aslında hiçbir zaman var olmadığı ve gerçekte herhangi özgün bir benzerinin olmadığı anlayışıdır. Hipergerçeklik, bizi gerçek olanı unutmaya davet eder. Özgün olarak bildiğimiz şeylere dayanmayan fiziksel gerçeklik yeni, daha özgün ve inanılır bir gerçeklik ile değiştirilir.

Günümüzde tamamen post-modern, kentsel, endüstriyel toplumumuzun ve medya kültürünün ürettiği gerçekliğin içerisinde yaşıyoruz. Bazıları için bu, tanınabilir herhangi bir gerçekliğe dayanmayan bir hayal dünyası, yani hipergerçeklik olmuştur. Detaylar da birçok taraf arasında gerçekleşen iş birliğinin bir sonucu olarak ortaya çıkar. Her ne kadar görsel anlatı, aynı kişi tarafından yazılıp çizilse de kaçınılmaz olarak nihai sonucu etkileyen editörler ve yayıncılar ile etkileşim kurmak zorundadır. İş birliğine dayalı yazma deneyiminde olduğu gibi detaylar, retoriğin oluşturulmasına dahil olan katılımcıların bir ürünüdür. Anlatan, hedef kitlenin anlamasını beklerken hedef kitle de yazardan anlaşılır bir şey sunmasını bekler. Bunun indirgemeci doğası, katılımcıların kendi bilgisi ile olaya dahil olmasına olanak sağlar. Böylelikle okuyucular, hayranlıkta bütünleşmeye başlar ve girdi, fikir, hikaye arkaplanı ve eleştiriler konusunda birbirine itimat ederler (Brown, 1987).

\section{Hakikat Sonrası}

Bilginin baş döndürücü bir hızla bireylere ulaşması ve her kişinin istediği gibi herhangi bir engel olmadan içerik üretebilmesi neyin doğru neyin yalan olduğunu ayırt etme adına gerçeğin temsilini daha da karmaşıklaştırır. Hipergerçek, nesnel olan bir gerçeklik karşısında kitlelerinin kişisel duygular ve çeşitli çıkarların ağırlık kazanması ile nesnel gerçekliğin silikleştirilmesi ve kamuoyunu etkilemesi olarak tanımlanır. Burada gerçek önemli değil, önemli olan kişisel çıkar ve menfaatlerin önemli hale gelmesi ve kişilerin isteklerine cevap verdirilmesidir. Ideolojide yalan ve gerçek artık birbirine geçmiştir. Gerçeklik dediğimiz olgular hiçbir zaman bizim kişisel özelliklerimizden ve olaylara bakış açımızdan bağımsız değildir. Hipergerçek kavramı daha çok 21. yüzyıl için kullanılmakta ve kitle iletişim araçlarının yalanı hiper gerçeklik yaparak sunduğu bir çağı temsil etmektedir. Siyasi gerçekler, bilimsel gerçekler, felsefi gerçekler, sanatsal gerçekler ve ahlaki gerçekler vardır fakat bunlar bükülebilir ve bağlamına göre değişebilir. Kant'ın iddia etmiş olduğu gibi, insan aklı objektif değerlendirmelere sahip olmadığından rasyonelitenin gerçek olgulara erişimi yoktur (1929). 
Jean Baudrillard artık simülasyon çağında yaşadığımızı savunur. Kitle iletişim araçları tarafından kontrol edilen görüntüler ve söylemler bize gerçeğin kendisini anlatmamaktadır. Anlatılan gerçeğin üstü örtülerek istenilen forma getirilmesiyle bize ulaştırılır ve bu hipergerçeklik tanımına girer. Yaşamımız içerisinde televizyon kadar ya da ondan daha etkili olan sosyal medya da hipergerçeklik yaratarak yalanların üzerini örtmekte, menfaat ve çıkar savaşlarına dönüşmektedir. Sahte hesaplar, sahte fotoğraflar kullanarak karşıt grupların arasına girerek yalan bilgiler, argo kelimeler kullanarak saldırılmaktadır. Bu nedenle, hipergerçek kavramıyla ortaya çıkan yalan gerçeklerin bükülerek iç içe geçirilmesi sonucunda neyin doğru neyin yanlış olduğu birbirine karışmakta ve hakikat sonrası (post-truth) oluşumu daha da belirginleşmektedir.

\section{Mekânsal Gazetecilik}

Hipergerçek anlatımı mümkün kılan teknolojilerinin sunduğu imkanlarla 2 boyutlu anlatımdan 3 boyutlu anlatıma geçilmiş, daha merak uyandıran bir izleyici deneyimi sunmayı ve okuyucuya çok daha canlı ve hatırlanmaya değer bir dünya sergilemeyi hedefleyen uygulamalar kitlelerle buluşmaya başlamıştır. Bireyleri melez mekânda konumlandırma yeteneğine sahip olan dijital haritalama sistemleri üzerine inşa edilen konumsal medya teknolojileri ile medyanın mekânsallaşmaya başladığını söyleyebiliriz. Bunun en bariz örneğini de mekansal gazetecilik uygulamalarında görmek mümkün.

Mekânsal gazetecilik, izleyicileri haber sunucularının yerine koyarak izleyicilere sürükleyici ve merak uyandıran bir izleme deneyimi sunar. Hipermetinsellik, geleceğin anlatım formatı ve gazeteciliğin geleceğidir. New York Times, Suriye'deki tahrip edilmiş bir çatıyı gösterdiği 3 boyutlu deneyimi hem zaman hassas bir hikaye olması hem de üstün teknoloji kullanmasıyla Emmy ödülü kazanmıştır. Medyanın ulaştığı alan ve işlevi arttıkça üç boyutlu, artırılmış gerçeklik ve sanal gerçeklik platformları da gazetecilerin fikirlerini paylaşma şeklini de belirlemeye devam etmektedir. Bir savaş alanında yürüdüğünüzü, üç boyutlu araziler üzerinde uçtuğunuzu, etkileşimli veri setlerini analiz ettiğinizi, sahnede ünlü bir kişinin yanında durduğunuzu veya uzayda gezgin bir aracın yanında ilerlediğinizi hayal edin. Artırılmış ve sanal gerçeklik teknolojilerinin Google, Apple, Facebook ve Snapchat gibi oluşumlar tarafından geliştirilmesiyle birlikte kullanıcılar, yakın zamanda daha kişisel deneyimlere maruz kalacaktır. Mekansal gazetecilik bu zamana kadar teknik platform sınırlamaları, uzun yapım süreçleri ve geleneksel medya ile karşılaştırıldığında göreceli olarak daha yüksek maliyetler gibi nedenlerden dolayı kısıtlanmıştır. 2017 yılı öncesine kadar mekansal gazeteciliğin çoğu, durum haberlerine odaklanmıştır. 2017 yılından önce bu deneyimler, yalnızca özel şekilde cihazlara indirilebilen bir uygulama içerisinde oluşturulabiliyordu. Bu durum karma gerçekliğin yayılması açısından büyük bir kısıtlılıktı, yüklemelerin kullanımı zordu. Ancak teknik gelişmeler, gittikçe bu yeni hikayelerin daha erişilebilir platformlarda sunulmasına ve daha hızlı bir şekilde iletilmesine olanak tanıdı. Bu teknoloji, gittikçe daha da ucuz ve hızlı hale gelerek bölgesel kaynakların ve geliştirilmiş bu gazetecilik ortamının kullanılmasına olanak sağlayacaktır.

Mekânsal gazeteciliği daha da etkisi altına alacak ve takip edilmesi gereken teknolojiler arasında 5G, nokta bulutu ve giyilebilir cihazlar bulunmaktadır. 5G, 
devasa miktarlarda verinin hemen hemen anlık olarak cihazlara yüklenmesine olanak sağlayacaktır. Sahadaki bir gazetecinin canlı olarak 360 dereceyle çektiği bir görüntünün kullanıcıların sanki gazetecinin bulunduğu noktadaymışçasına kullanıcılar tarafından görüntülenebildiğini hayal edin. Nokta bulutu, karma gerçeklikte paylaşılan deneyimlere ve nesne devamlılığına olanak sağlayan dünya veri haritalaması anlamına gelmektedir. Giyilebilir teknolojinin ilk nesilleri haberleri görüş alanına getirecek ancak deneyimi aktarmayacak olan basit ekranlı gözlükler olacak (North gibi). Daha önce bahsedilen nokta bulutuna erişim sağlayabilen ekranlar veya en azından dünyamızın doğru bir şekilde haritalanmasına olanak sağlayacak derinlik algılayıcı kameralar donanımcılar tarafından oluşturulan yeni bir mekânsal gazetecilik ve bilgi çağı ortaya çıkacak. Böylelikle içeriği tüketenler bu hiper ortamda "gerçekliğin" içinde yer alabilecek. En güçlü duyum ve görüş artık paylaşılan bir deneyim olmayacak; teknolojiyi giyen kişinin veya bir yapay zeka uygulamasının seçtiği üç boyutlu medyaya bağlı olarak kişiselleştirilecek.

Geliştirilmiş bu gazetecilik ortamı, empati yaratmak ve hikaye anlatımına ait unsurların kullanıcının belleğinde derinden yer etmesi açısından oldukça önemli olacaktır. Bellek, yüksek oranda mekansal kavrayışa bağlıdır. Hafızanızda hatırlamak istediğiniz unsurları söz konusu konuma yerleştirdiğinizde belleğiniz daha canlı ve uzun ömürlü olacaktır (Cadoux, 2019). Belleğiniz ve empatiniz, mekansal merkezli deneyimlerinize daha çok hizmet ettiğinden mekansal gazetecilik, haberleri ve gazeteciliği daha da etkili hale getirecektir. Aynı şey, kaliteli gazeteciliğin hikaye anlatımından elde edilen izlenimler için de geçerlidir (Cadoux, 2019). Ancak unutulmaması gerekir ki birçok olaya ilişkin salt deneyimimiz, "haber" denilen simülasyon aracılığıyla sağlanır. Medya ve resmi haber hizmetleri; salt bir gerçekliğin ilüzyonunu, durumun gerçekliğini veya doğruların nesnelliğini korumak için var olan kuruluşlardır (Baudrillard, 1994/1981). İçeriğin oluşturulmasında retorik kurallarının yanı sıra haber yapımında ve dağıtımında kullanılan medya filtreleri göz önünde bulundurulduğunda, gerçeklik veya doğruluk kolayca sorgulanabilir. Haber medyası, bir olaya veya konuya ilişkin bakış açısını kolaylıkla değiştirebilir. Gerçek ötesi, nesnel hakikatin reddedilmesini veya bundan uzaklaşılmasını ifade eder. Hakikatler veya gerçekler, ideolojilere hizmet etmek amacıyla yalanlar ve kafa karıştırıcı taktikler ile değiştirilir. Aksi ispatlanması zordur çünkü kimse "gerçeğin" ne olduğunu bilmemektedir. Gerçeğin kendisinin tanımlanması zordur ve aksi kolaylıkla ispatlanabilir. Bu, gerçeğin bir şekilde susturulması ve şüpheli görünmesinin sağlanmasıdır. Yalan haberler, gerçek ötesinin bir göstergesi veya sonucu olarak görülebilir. Bu bağlamda yalan haberler, aynı zamanda hipergerçeklik olarak da düşünülebilir.

\section{Tartışma ve Sonuçlar}

Hipergerçekliğin temeli postmodernist teori olup, orijinal ile kopya arasındaki ilişkiyi ifade ederek, oyun ve illüzyon arasındaki sınırları bulanıklaştıran mutlak sahtenin nasıl gerçekçe üretildiğini vurgulamaktadır (Eco, 1976). Bu post-modern çağda kopyalanan gerçekten (orijinalden) daha gerçekçi bir etki yaratmayı amaçlayan bir estetiğe dayalı üretim veya kopyalama yöntemi söz konusudur. Özgün nesnenin varlığının getirdiği etkiyi hatırlatmaya çalışarak özgün olan nesneden daha da gerçekçi olmaya çalışma çabası 
söz konusudur (Baudrillard, 1994). İletişim, post-modern medya ve mesajlarla donanmış toplum tarafından şekillenir. İletişimin sınırları, temsillerden simülasyona olan geçişle çizilir. Tüm gerçeklik ve anlam, göstergelerle ve sembollerle değiştirilmiştir. Bilginin miktarı, giderek artarak bilgi artışına neden olmaktadır ancak taşıdıkları anlam çok azdır çünkü anlamın içi boşaltılarak ideolojik veya retoriksel bir malzeme olarak kullanılmak amaciyla başka bir şeye dönüştürülür.

Baudrillard, medya ve simüle ettikleri gerçeklikten daha az "gerçek" olmayan gerçeklik simülasyonlarının varlığı ile donanmış bir kültürde "gerçekliğin yok olması" ile karşı karşıya olduğumuzu ileri sürmektedir (Baudrillard, 1994). Simülasyonlar/ replikalar, dünyayı kavrayış şeklimizi şekillendirmeye başlamıştır. İnsan deneyimi, gerçekliğin bir simülasyonuna indirgenmektedir. Baudrillard, deneyimlerimizin "gerçek" olan ile simülasyon arasındaki farkın yok olduğu hazırlanmış gerçeklerden ibaret olduğunu ileri sürer (Baudrillard, 1994). Simülarklar; simülasyonun, göstergenin gerçekliğin kendisi olması gibi gerçekliğin sürekli olarak gerçeklik göstergelerinin tekrar olarak kullanımından ve oluşumundan meydana geldiği hipergerçeklik durumundan ibaret olduğu, kaybedilmiş gerçekliğin göstergesi olarak anlaşılabilir. Daha da detaylı ifade etmek gerekirse, Baudrillard'ın simülark türleri; gerçekliğin yansıtılmasını, gerçekliğin örtülmesini, gerçekliğin yokluğunun saklanmasını ve son olarak simülarka (hipergerçeklik) dönüşümü kapsar (Baudrillard, 1994).

Gerçek ötesi, performans ve propaganda ile iç içe geçmiş siyasi bir ideolojiyi kapsar. Bunu çevrimiçi algoritmalarda görmek mümkün. Yapay zeka ile öğrenme sayesinde kullanıcıya önerilerin ve ürün tavsiyelerinin sunulması, diğer kanallarda da görülmeye başlamıştır ve promosyon aracı olmaktan başka bir şey değildir. Doğal içerik ve gizlice kendisine para ödenen fenomen pazarlamacılığı, pazarlamanın yalan haberleri niteliğinde karşımıza çıkmaktadır. Doğal reklamlar, "yalan haber" furyasının daha etkili bir şekilde anlaşılabilmesi için pazarlamayı incelemenin tek yolu değildir. Google'un "organik" sıralama algoritması, kullanıcıların her seferinde arama yaptıklarında kullanıcıları en iyi sonuçla (veya en azından verilerin önerdiğinin en iyisiyle) eşleştirmeyi amaçlayan arama motoru fikri ile oldukça karmaşık bir oluşum haline gelmiştir. Ancak en iyi ne anlama gelmektedir? Örüntü tanıma faydalı bir araçtır ancak farklılığın, bireyselliğin ve olağandışı olarak görülebilecek düşünme tarzının aslında güçlü bir özellik olduğu alanlarda sadece tekdüzeliğin sağlanması için kullanıldığında faydalı bir araç değildir. Size sunulan içeriği size zorla kabul ettiren bu algoritma anlayışı, Facebook ve Twitter gibi her sosyal medya kanalında ve kaydedilmesine karar verilen her şeyde mevcuttur. Algoritmalar, normal şartlar altında bir editörün sunacağı şekilde size sunulan içeriği (ve dolayısıyla aslında tüketmeyi amaçladığınız şeyleri) size zorla kabul ettirmektedir. Ancak aradaki fark, doğru olduğu düşünülen şekilde ölçülere ve sayılara yani sonuçlara odaklanmasıdır. Kullanıcının etkileşimde bulunmasını teşvik edecek veya bir konuda kişiye meydan okuyacak içeriği sunmaktan ziyade kullanıcının büyük ihtimalle beğeneceği ve paylaşacağı içeriği teşvik etmektedir. $\mathrm{Bu}$, kitleleri çekmek, üzerinden büyük veri toplamak, tektipleştirmek ve kitleleri yönetmek adına medya sahipleri için sadece başka bir araçtır. Bu gerçekten yola çıkarak, teknolojik gelişmenin insanoğlunu bütünleştirdiği ve özgürlügünü artırdığı savı da sadece başka bir büyük anlatıdır diyebiliriz. 


\section{Kaynaklar}

Adorno, T. W., \& Horkheimer, M. (1997). Dialectic of enlightenment (Vol. 15). Verso Books.

Ambrose, D. (2009). Lyotard and Levinas: the logic of obligation. JAC, 633-659.

Barthes, R. (1972). Mythologies. 1957. Trans. Annette Lavers. New York: Hill and Wang, 302-06.

Barthes, R. (1977). Rhetoric of the image. In Heath, S. (Ed.) Image, music, text. London: Fontana

Baudrillard, J. (1975). The mirror of production (Vol. 17). St. Louis: Telos Press.

Baudrillard, J. (1983). The precession of simulacra. New York.

Baudrillard, J. (1988). The hyper-realism of simulation. Jean Baudrillard: selected writings, 143-147.

Baudrillard, J. (1994). Simulacra and simulation. University of Michigan press.

Baudrillard, J. (2005). Violence of the virtual and integral reality. International Journal of Baudrillard Studies, 2(2), 1-16.

Baudrillard, J. (2019). For a Critique of the Political Economy of the Sign. Verso Books.

Best, S., \& Kellner, D. (1991). Foucault and the Critique of Modernity. In Postmodern Theory (pp. 34-75). Palgrave, London.

Bevilacqua, V. M. (1965). Adam Smith's Lectures on rhetoric and belles lettres. Studies in Scottish Literature, 3(1), 41-60.

Bilandzic, H., \& Busselle, R. (2013). Narrative persuasion. The Sage handbook of persuasion: Developments in theory and practice, 2, 200-219.

Bitzer, L. F. (1968). The Rhetorical Situation. Philosophy and Rhetoric. In J. Luraites, C.

Braet, A. C. (1992). Ethos, pathos and logos in Aristotle's Rhetoric: A reexamination. Argumentation, 6(3), 307-320.

Brown, R. H. (1987). Society as text: Essays on rhetoric, reason, and reality. University of Chicago Press.

Browning, G. K. (2000). Lyotard and the End of Grand Narratives. Cardiff: University of Wales Press.

Browning, G. K. (2003). Lyotard and Hegel: what is wrong with modernity and what is right with the philosophy of right. History of European ideas, 29(2), 223-239. 
Burke, K. (1966). Language as symbolic action: Essays on life, literature, and method. Univ of California Press.

Cadoux, M. (2019). "AR and VR will make spatial journalism the future of reporting". Erişim 5 Ocak 2020: https://venturebeat.com/2019/11/10/ar-and-vr-willmake-spatial-journalism-the future-of-reporting/

Canter, D. V., Grieve, N., Nicol, C., \& Benneworth, K. (2003). Narrative plausibility: The impact of sequence and anchoring. Behavioral Sciences \& the Law, 21(2), 251-267.

Cheney, G. (1983). The rhetoric of identification and the study of organizational communication. Quarterly journal of speech, 69(2), 143-158.

Cohen, A. (2010). Myth and myth criticism following the dialectic of enlightenment. European Legacy, 15(5), 583-598.

Condit, \& S. Caudill (Eds.), Contemporary Rhetorical Theory (pp. 217-225). New Jersey, USA: Guilford Press.

D’Angelo, F. J. (1975). A conceptual theory of rhetoric. Cambridge, MA: Winthrop.

D'Angelo, F. J. (2009). The rhetoric of intertextuality. Rhetoric Review, 29(1), 3147.

De Saussure, F. (2006). Nature of the linguistic sign. Images: A reader, 105-107.

Denzin, N. K. (1986). Postmodern social theory. Sociological theory, 4(2), 194-204.

D'haen, T. (1983). Text to reader: a communicative approach to Fowles, Barth, Cortazar and Boon (Vol. 16). John Benjamins Publishing.

Eco, U. (1979). A theory of semiotics (Vol. 217). Indiana University Press.

Edbauer, J. (2005). Unframing models of public distribution: From rhetorical situation to rhetorical ecologies. Rhetoric society quarterly, 35(4), 5-24.

Ellis, G. (1995). Storytelling and storybooks: A broader version of the communicative approach. ESOL France-British Council, 2(1), 89-100.

Evans, J., \& Hall, S. (Eds.). (1999). Visual culture: The reader. Sage.

Fawcett, R. P. (2000). A theory of syntax for systemic functional linguistics (Vol. 206). John Benjamins Publishing.

Gane, M. (2002). Baudrillard's bestiary: Baudrillard and culture. Routledge.

Gottdiener, M. (1985). Hegemony and mass culture: A semiotic approach. American journal of sociology, 90(5), 979-1001.

Grimaldi, W. M. (1978). Rhetoric and Truth: A Note on Aristotle." Rhetoric" 1355a 21-24. Philosophy \& Rhetoric, 173-177.

Habermas, J. (1988). Legitimation Crisis. Oxford: Polity Press . 
Habermas, J., \& Levin, T. Y. (1982). The entwinement of myth and enlightenment: Re-reading dialectic of enlightenment. New German Critique, (26), 13-30.

Jappy, T. (2013). Introduction to Peircean visual semiotics. A\&C Black.

Jenks, C. (Ed.). (2002). Visual culture. Routledge.

Kant, I. (1929). Critique of Pure Reason, trans. Norman Kemp Smith, (Boston/New York: Bedford/St. Martin's.

Kellner, D. (1989). Jean Baudrillard: From Marxism to postmodernism and beyond (Vol. 179). Stanford, CA: Stanford University Press.

Lyotard, J. F. (2000). The postmodern condition. Sociology of Education: Theories and methods, 1, 362 .

Lyotard, J. F., \& Brügger, N. (2001). What about the Postmodern? The Concept of the Postmodern in the Work of Lyotard. Yale French Studies, (99), 77-92.

Lyotard, J. F., \& Engelmann, P. (1986). Das postmoderne wissen: Ein bericht. Böhlau.

MacDonald, M. (2006). Empire and communication: the media wars of Marshall

McLuhan. Media, Culture \& Society, 28(4), 505-520.

Malpas, S. (2003). Jean-François Lyotard. Psychology Press.

Malpas, S., \& McGowan, K. (2002). 5 Postmodernism. Year's Work in Critical \& Cultural Theory, 9(1).

Merrin, W. (2005). Baudrillard and the media: A critical introduction. Polity.

McKerrow, R. E. (1989). Critical rhetoric: Theory and praxis. Communications Monographs, 56(2), 91-111.

Moriarty, S. E. (2002). The symbiotics of semiotics and visual communication. Journal of Visual Literacy, 22(1), 19-28.

Moriarty, S. E. (2005). Visual semiotics theory. Handbook of visual communication: Theory, methods, and media, 8, 227-241.

Morris, C. W. (2014). Writings on the general theory of signs (Vol. 16). Walter de Gruyter.

Özgen, N. (2019). Siyasal Sistemler Bağlamında Sansür Kavramı Örnek Olay: İliştirilmiş Gazetecilik Pratiği. Electronic Turkish Studies, 14(6).

Peirce, C. S. (1955). Philosophical writings of Peirce(Vol. 217). Courier Corporation.

Poster, M. (1984). Foucault, Marxism, and History (p. 962). Cambridge: Polity Press. 
Potter, J. (1996). Representing reality: Discourse, rhetoric and social construction. Sage.

Smith, J. K. (2006). Who's Afraid of Postmodernism?(The Church and Postmodern Culture): Taking Derrida, Lyotard, and Foucault to Church. Baker Academic.

Smith, M. W. (2001). Reading simulacra: Fatal theories for postmodernity. SUNY Press.

Smith, R. G. (2015). Jean Baudrillard: From hyperreality to disappearance. Edinburgh University Press.

Theguardian. (2019). "Global attention span is narrowing and trends don't last as long, study reveals”. Erişim tarihi 19 Aralık 2020, https://www.theguardian.com/ society/2019/apr/16/got-a-minute-global-attention-span-is-narrowing-study-reveals

Vatz, R. E. (1973). The myth of the rhetorical situation. Philosophy \& rhetoric, 154-161. 